\title{
Chalepogenus roitmani Roig Alsina (Hymenoptera: Apidae: Tapinotaspidini): description of the male and new geographical records for the species
}

\author{
JUAN PABLO TORRETTA ${ }^{1}$, HUGO J. MARRERO ${ }^{1} \&$ ARTURO ROIG ALSINA ${ }^{2}$ \\ ${ }^{1}$ Cátedra de Botánica Agrícola, Facultad de Agronomía, Universidad de Buenos Aires, Av. San Martín 4453, C1417DSE, Buenos \\ Aires, Argentina.E-mail:torretta@agro.uba.ar, hugomarrero@gmail.com \\ ${ }^{2}$ Museo Argentino de Ciencias Naturales “Bernardino Rivadavia”, Av. A. Gallardo 470, C1405DJR, Buenos Aires, Argentina. \\ E-mail: arturo@macn.gov.ar
}

Bees of the genus Chalepogenus Holmberg collect oils offered as a reward by flowers of a few plant families: Iridaceae, Calceolariaceae (formerly included in Scrophulariaceae, see Olmstead et al. 2001), and Solanaceae (Vogel 1974; Cocucci 1991; Roig Alsina 1999; Cocucci et al. 2000; Machado 2004). The oil-collecting structures of these bees are situated on the forebasitarsus and show interspecific variation related to the type of flower they visit (Roig Alsina 1997; Cocucci et al. 2000).

The genus Chalepogenus exclusively occurs in South America, where twenty-one species are currently recognized (Roig Alsina 1999). Most species are known from both sexes, except for C. roitmani Roig Alsina, from Argentina, known only from the female, and for $C$. bicellularis Roig Alsina, from Peru, known from the male; the sexes of a third species, C. crassifasciatus Roig Alsina, have been associated with some doubts (Roig Alsina 1999). The sexual dichromism and dimorphism of $C$. muelleri (Friese), type species of the genus, misled many authors in the interpretation of the taxonomic limits of Chalepogenus, since its females were included in Tapinotaspis Holmberg (Roig Alsina 1997). The newly discovered male of $C$. roitmani has an extensive yellow maculation (Figs. 1-2), whereas the female has the integument entirely black (Fig. 3), being $C$. roitmani the second dichromic species in the genus.

Chalepogenus roitmani was included by Roig Alsina (1999) in the muelleri species-group, based on the general similarity of its female to that of $C$. muelleri. This group, which also included $C$. unicolor Roig Alsina, is characterized mainly by apomorphies in the males, particularly on the hidden seventh metasomal sternum and the genitalia. The morphological characteristics of the discovered male $C$. roitmani corroborate that this species belongs in the muelleri species-group.

In this paper, we report the discovery of the male of Chalepogenus roitmani Roig Alsina, and provide its description, as well as new geographical records for the species. Morphological characteristics of the male corroborate that $C$. roitmani belongs in the $C$. muelleri species group.

The material studied is deposited at the Facultad de Agronomía, Universidad de Buenos Aires, Argentina, and at the Museo Argentino de Ciencias Naturales, Buenos Aires, Argentina. The following abbreviations are used in the descriptions: S1-S7, metasomal sterna 1-7, respectively; T1-T8, metasomal terga 1-8, respectively; DF, diameter of flagellum.

\section{Chalepogenus roitmani Roig Alsina}

(Figs. 1-5)

Chalepogenus roitmani Roig Alsina, 1999: 77

Description. Male. Total length 8.7-9.5 mm ( $\mathrm{n}=5)$, forewing length 7.0-7.8 mm ( $\mathrm{n}=5)$.

Coloration. Head black, with following yellow marks: labrum, clypeus (except tentorial pits), lower paraocular area (from clypeus to level of antennal socket), supraclypeal area (varying from central mark to band between subantennal sutures), small median mark on malar area, scape, except longitudinal dark band on inner surface, and basal mark on mandible. Pedicel dark; flagellum dark brown with yellowish-brown lower surface. Thorax and propodeum blackish, except anterior yellow mark on tegula and in some specimens small yellow spot on pronotal lobe. Coxae and trochanters 